О.В.Завальнюк,

кандидат педагогічних наук, викладач НПУ імені М.П.Драгоманова

\title{
СПОРТ ЯК СИСТЕМНИЙ ОБ’ЄКТ УПРАВЛІННЯ
}

Загальна природа управління дає можливість визначити його як елемент і одночасно функцію організаційно-економічної системи, яка забезпечує зберігання їх структури, підтримку режиму діяльності, реалізацію мети діяльності та програми іії досягнення. Поняття «управління» означає діяльність 3 керівництва ким-небудь або чим-небудь. У загальному розумінні управління - це цілеспрямований вплив на складну систему. У широкому розумінні воно $\epsilon$ особливим видом діяльності, який здатний перетворити неорганізований натовп в ефективну цілеспрямовану і продуктивну групу. Здійснити це можна лише через процес планування, організації, мотивації та контролю спільних дій. У вузькому розумінні управління - це діяльність, яка спрямовує та регулює суспільні відносини за допомогою спеціального органу. За допомогою управління узгоджуються, координуються, кооперуються індивідуальні зусилля, вирішуються завдання і досягаються загальні цілі. Соціальне управління існує в межах взаємодії людей, і саме через нього формуються зв'язки між окремими суб'єктами. Таким чином, управління являє собою діяльність уповноважених органів, що спрямована на досягнення конкретних завдань за допомогою управлінських методів, способів та функцій [1].

Досягнення стратегічної мети управління можливе через вирішення усього спектру завдань шляхом реалізації функцій управлінської діяльності в певній галузі. Функція (в перекладі з латинської «завершення, виконання») - це: зовнішній прояв властивостей певного об'єкта в межах певної системи відносин, до якої він належить; вид зв'язку між об'єктами, який зумовлює зміну одного з них завдяки зміні іншого (у такому випадку другий об'єкт визначають як функцію першого); стандартизована соціальна дія, що регулюється певними нормами і контролюється соціальними інститутами; діяльність певного елемента соціальної системи з метою реалізації цілей та інтересів певних соціальних стратів і класів. 
У вужчому значенні поняття функції охоплює визначене коло завдань та системний інструментарій певної галузі діяльності $[2,171]$. Функція, як один із провідних змісто- та системоутворювальних компонентів будь-якої організованої, цільової, планової, системної діяльності, є тим чинником, який зумовлює доцільність, необхідність, предметність існування структурно-системних утворень. Надзвичайно важливою постає ця категорія для управлінської діяльності, адже вона є основою для формування ст. ктури системи управління, якісної та ефективної взаємодії між іiі підсистемами, компонентами, об'єктами.

Науковий дискурс щодо тлумачення поняття «функція управління» триває й досі, і в ньому не існує єдиного загальноприйнятого визначення цього терміна. До змістоутворювальних ознак поняття «функція управління», залежно від певного науково-теоретичного підходу, науковці відносять: реальний, силовий, цілеспрямований, організуючий вплив на об'єкт управління, що характеризується самостійністю, однорідністю, складністю та стабільністю; вид управлінської діяльності, що виокремився внаслідок розподілу управлінської праці; спрямованість на досягнення поставленої мети та вирішення завдань управління; складові змісту, окремі періоди (стадії), напрями управлінської діяльності; здійснення відповідно до законодавства спеціально створеними органами влади; здійснення шляхом застосування специфічних методів державного управління [3, 176].

Функціонування та розвиток певної системи, згідно з визначеними параметрами, забезпечують відповідні механізми управління. Це поняття позначає закономірно виниклу в процесі еволюціiі, специфічно організовану форму руху матерії, яка полягає в цілеспрямованому багатоциклічному перетворенні інформації 3 наявністю зворотних зв'язків для збереження сталості об'єкта управління, системи, іiі розвитку, подальшого підвищення рівня іiі організації шляхом відбору та накопичення інформації $[4,63]$.

Процес управління в системах можливий лише за умови дотримання певних вимог, а саме: суб'єкт управління має бути реально здатним змінювати стан об' єкта управління відповідно до прийнятих рішень; механізм управління повинен характеризуватись цілеспрямованими (не випадковими), пов'язаними між собою керівними впливами; суб'єкт управління (система управління) повинен мати змогу вибирати рішення з певного набору можливих рішень, тобто добирати оптимальний напрямок руху; суб'єкт управління (система 
управління) повинен мати у своєму розпорядженні матеріальні, фінансові, трудові, інформаційні та інші ресурси, що забезпечують реалізацію вибраних керівних впливів; суб'єкт управління повинен знати не тільки мету та кінцевий стан, якого потрібно досягти, а й поточний стан об'єкта управління, в якому він перебуває в даний момент; об'єкт управління перебуває під впливом не лише системи управління, а й зовнішнього середовища, на яке об'єкт управління і сам певною мірою впливає; об'єкт управління повинен мати здатність переходити до різних станів [5].

Необхідність розробки стратегії управління пов'язана з осмисленням того, що організації мають постійно вдосконалюватися, здобуваючи нове знання як про себе, так і про своє оточення. Будьяка сучасна організація діє в умовах зростання конкуренції, яка має хаотичний, складний і глобальний характер. Це вимагає максимально швидких і адекватних відповідей на конкурентні виклики в умовах обмежених ресурсів. Тому знання співробітників і організації в цілому перетворюються на цінний ресурс, що враховується нарівні з іншими матеріальними ресурсами.

Нематеріальна природа знань часто ускладнює їх відтворення, тому знання можуть розглядатися як важливий елемент у створенні стрижневих спрямувань. Управління знаннями дає змогу формулювати й вирішувати правильні завдання, визначати стратегію, що, свєю чергою, передбачає постановку цілей і відповідних завдань 3 наступним ефективним їх вирішенням [6]. Така специфіка організації сучасної системи управління повною мірою стосується сфери спорту.

Сучасний спорт можна визначити як складний системний об'єкт управління. Для досягнення поставлених цілей у спорті, як і в інших сферах життя суспільства, необхідною умовою $є$ здійснення оптимального управління. Успішність вирішення проблем у сфері спорту залежить від правильності обраної організаційної структури управління.

Як об’єкт галузевого соціального управління (менеджменту), спорт є сукупністю спеціалізованих державних установ, громадських об'єднань, комерційних організацій, які здійснюють фізичне вдосконалення суспільства. Відповідно спеціалізовані установи, громадські об'єднання, комерційні організації спортивної спрямованості постають класифікаційною одиницею, первинною ланкою спортивної галузі. До них належать спортивні клуби, різноманітні спортивні школи, спортивні команди, спортивні споруди. Усі вони 
є соціально керованими об'єктами, мають внутрішню структуру, зовнішню форму і правове закріплення. Таким чином, спорт інституюється через низку організацій відповідної спрямованості [7, 84]. Здійснення управління у сфері спорту має забезпечити поступальний розвиток фізичної складової кожної особистості.

Специфіка феномену фізичної культури і спорту полягає, насамперед, у тому, що вони поєднують в єдине ціле соціальне та біологічне в людині. Глибокий взаємовплив соціального та біологічного відбувається як протягом індивідуального життя кожної сучасної людини, так і протягом історичного процесу становлення людини розумної. Один із аспектів дослідження цього процесу стосується вивчення психофізіологічних основ засвоєння індивідом соціальної програми і її трансформації в індивідуальну програму. Як зазначає М.Дубінін, сприйняття соціальної програми відбувається на основі їі впливу на процеси розвитку особи з генетичною програмою. Кожна людина, маючи унікальну генетичну організацію, має єдиний у своєму роді спосіб реагування на соціальні і фізичні впливи середовища. Різноманітність людей, що визначається унікальністю кожної людини за ії генетичною конституцією, часом створюють складні проблеми виховання $[8,56]$.

Біологічні особливості кожної людини впливають на процес формування, на властивості людської особистості в цілому, на такі їі риси, як обдарованість, емоційність. Проте цей вплив біологічного створює тільки тло, впливає на вираженість тих чи інших рис особистості; він не стосується якісних сторін змісту свідомості, які визначаються безпосередньою участю людини в соціально-історичному процесі [9, 47-48].

У глобальному плані формування і розвиток особистості можна розглядати як процес засвоєння нею соціальних програм спадкоємності $[10,87]$, що склалися в суспільстві на певному історичному етапі. Цей процес спрямовується суспільством і здійснюється за допомогою спеціальних соціальних інститутів, насамперед системи освіти і виховання. Така діалектична єдність біологічного та соціального має вияв й у фізичному розвитку особистості, зокрема, - у спортивній діяльності, успішність якої значною мірою залежить від ефективності системи соціального управління цим процесом.

Процес фізичного розвитку будь-якої людини полягає у вдосконаленні форм і функцій організму, реалізації його фізичних можли- 
востей. Проте було б неправильно вважати, що біологічні процеси розвитку людини відбуваються ізольовано від іiі соціальних функцій, поза впливом суспільних відносин. Вплив природних чинників на розвиток фізичного потенціалу людини має об'єктивний характер, але його специфіка полягає в тому, що він може посилюватися або послаблюватися залежно від активності людини, яка може свідомо змінювати перебіг цього процесу, спираючись на пізнання його законів і сутності $[11,3]$. Це дає змогу визначити фізичну культуру та спорт як важливі складники соціокультурного розвитку як особистості, так і всього людства.

М.Віленський визначає ключові характеристики фізичної культури особистості - якісний розвиток і інтегральний результат професійної підготовки. Розроблена дослідником модель фізичної культури особистості охоплює три основні складники: мотиваційноціннісні орієнтації (знання, мотиви, інтереси, установки, переконання, потреби); фізична досконалість особистості (рухові уміння, рухові навички, фізичний розвиток, фізична підготовленість); фізкультурно-спортивна діяльність (пізнавальна, пропагандистська, інструктивно-педагогічна, суддівська, організаторська, діяльність самоудосконалення) [12, 32].

Ця модель екстраполюється на фізичну культуру особистості незалежно від іiі професійної приналежності $[13,12]$. Умовою поступального розвитку фізичної культури, на нашу думку, є відповідна соціокультурна ситуація, що передбачає функціонування спорту як важливого об'єкта управління.

Характеризуючи структуру фізичної культури суспільства, В.Видрін зазначає, що вона сформувалася історично, у процесі задоволення особистісних і суспільних потреб. Виникнення й розвиток фізичної культури, як і інших видів культури (виробничої, художньої, політичної), зумовлені потребами людського суспільства в процесі його розвитку. До найзагальніших потреб суспільства дослідник відносить необхідність створення здорової, діяльної, мобільної нації, здатної ефективно працювати і захищати себе у разі необхідності. Будь-яке суспільство потребує всебічно, гармонійно розвинених людей, що вимагає створення об'єктивних умов для вільного розвитку їхніх сил, здібностей, обдарувань. Міра сформованості особистісної потреби у власному всебічному, гармонійному розвитку залежить, насамперед, від рівня культури людини, iіi 
вихованості й освіченості $[14,18]$.

Втім, ототожнення культури особистості лише з іï духовними атрибутами, їх протиставлення тілесному буттю людини спричиняє певні негативні наслідки. На теоретичному рівні це призводить до відсутності цілісної концепції особистості, яка б гармонійно поєднувала тілесні та духовні засади власного існування, що перешкоджає практичній діяльності в сфері виховання, освіти, культурної політики. На повсякденному рівні протиставлення «людини тілесної» та «людини духовної» постійно відтворюється соціальною практикою (зокрема, у сфері спорту). Тим самим, з одного боку, девальвується ціннісний смисл, значущість тілесності людини, iї соматичної культури, соціального статусу і престижу фізичного іміджу особистості. 3 іншого боку - зворотною реакцією може стати своєрідна «соматизація» людини, абсолютизація ії «м’язових», «бюстовосідничних» або інших рис зовнішності. Ці крайнощі виникають через вилучення тілесно-фізичних характеристик людини з процесу нормальної культурної соціалізації, з системи соціокультурних цінностей суспільства та особистості $[15,61]$. Вони засвідчують серйозне порушення механізмів управління спортивною діяльністю на рівні соціуму.

До негативних наслідків дихотомічного підходу, який роз'єднує тілесність та духовність як складники соціокультурного розвитку, належать: поглиблення й загострення проблем здоров'я, значною мірою спричинені «соматичним негативізмом», антикультурним за своєю сутністю; зростання девіантної поведінки (в ситуації, коли розвиток «людини тілесної» не пов'язаний з ії культурноморальним розвитком); закріплення умов (поряд з економічними й іншими факторами) для формування «одновимірної», «часткової» людини, людини-функції з акцентом на «раціо» або на «фізику»; відсутність у значної частини людей естетично прийнятних навичок різних (насамперед, повсякденних) видів рухової діяльності [16, 117].

Зазначені обставини спричиняють необхідність усвідомлення людської тілесності як об'єкта наукового аналізу, як реальної цінності індивіда, суспільства, людства в цілому, як соціально-особистісної (а не тільки біологічної) цінності, як рівноправного елемента соціокультурного процесу. Як наголошує І.Биховська, культура знаходить у феномені людського тіла (як і в будь-якому іншому матеріальному об'єкті, що є частиною культурного простору) можливість бути «в-тіленою», тобто представленою в тілі. Культурні

172 ISSN2078-8142Мультиверсум. Філософський альманах.-2015.-Випуск 3-4(141-142) 
засади соціального життя, концентровані в них регулятивні принципи будь-якого виду людської практики, які визначають їі зміст і спрямованість, можуть виявити себе лише через певні реально дані явища, процеси та їх результати. Розмаїття феноменів у соціальній життєдіяльності людини породжує різноманіття культурних форм, в яких дістає свій вираз певна система культурних цінностей, норм, символів. Тому об'єктивація матеріальних форм вияву культурних засад є однією з базових проблем аналізу будь-якої сфери діяльності людини - господарської, естетичної, релігійної. Проте, мабуть, до жодної сфери людської діяльності поняття «втілення» (як вияв певної системи культурних цінностей) не має такого безпосереднього відношення, як до сфери культивування фізичних якостей людини, іiі тіла. Останнє перетворюється з природної матерії на носія культурних атрибутів людської цивілізації $[17,6]$. Відповідно воно постає важливим об'єктом соціального управління.

У культурному просторі тіло, що перебуває в стані саморуху, має набути здатність до самовизначення, на певному етапі свого розвитку «помітити себе», стати для самого себе предметом і продовжувати своє подальше розгортання. У цьому аспекті фізична культура як феномен загальної культури унікальна. Вона є найпершим і базовим видом культури, який формується в людині, може значно впливати на стан організму, психіки, статус людини $[18$, 24-25]. Однак потенціал фізичної культури та спорту може повною мірою реалізуватися лише за умови їх перетворення на об'єкт управління, яке здійснюється суспільством через мережу відповідних соціальних інститутів.

Фізична культура та спорт являють собою соціальний чинник цілеспрямованого впливу на процес фізичного вдосконалення людини, що дає змогу забезпечити спрямований розвиток життєво важливих фізичних якостей і здібностей особистості. Процес формування фізичної культури особистості відбувається на засадах єдності інтелектуального, соціально-психологічного і рухового компонентів [19, 26].

Однією з форм спрямованого функціонування в суспільстві, а саме -педагогічно організованим процесом передачі і засвоєння іiі цінностей - $\epsilon$ спортивна діяльність, основу якої становить фізичне виховання. На думку вчених, особливості фізичного виховання визначаються, насамперед, тим, що цей процес забезпечує спрямоване 
формування рухових навичок, розвиток фізичних якостей людини, сукупність яких визначає іiі фізичну дієздатність. У цьому аспекті спорт є формою соціального впливу на біологічний за своєю природою розвиток організму людини $[20,4]$. Як об'єкт управління спорт забезпечує різноманітні можливості такого цілеспрямованого впливу, тим самим виконуючи важливу соціальну роль.

Тому на сучасному етапі для будь-якої держави актуальність розвитку спорту як об'єкта управління, насамперед, визначається його соціальними функціями. Особливо важливо підкреслити значення для суспільства інтенційних цінностей, які розкривають значущість і престижність фізичної культури та спорту серед інших соціальних явищ. Фінансування, правова основа, сформованість позитивної громадської думки - це основні показники, що характеризують рівень значущості інтенційних цінностей спорту в певному соціумі. Ці показники значною мірою засвідчують рівень цивілізованості суспільства, розвитку культури країни в цілому [21, 3].

Водночас в умовах розвитку ринкового суспільства відбувається швидка комерціалізація сфери спорту. Фактично спорт перетворився на професію набагато раніше, ніж у 1974 р., коли було прийнято рішення Міжнародного олімпійського комітету про матеріальну компенсацію за час, витрачений спортсменами високого рівня для підготовки до змагань. Це рішення фактично визнало реальність ситуації, коли спорт найвищих досягнень і любительство виявилися несумісними. Уже в середині 50-х років XX ст. така ситуація визначила новий статус спорту в сучасному світі і вплинула на різні аспекти спортивного життя $[22,6]$. Зокрема, вона суттєво змінила систему управління спортивною діяльністю, визначивши загальну перспективу розвитку професійного спорту.

Комерціалізація сучасного спорту визначає гостроту конкуренції в цій сфері людської діяльності. Тому має рацію М.Візітей, який доходить висновку, що сучасна професійно-комерційна спортивна діяльність може бути розглянута як контркультура, оскільки $\epsilon$ сферою антагоністичних відносин, сферою, де гострота міжособистісних відносин виявляється особливо сильно вираженою: адже настанова на жорстке фізичне пригнічення суперника зазвичай реалізується тут відкрито, практично-діяльнісно, у формах, які у багатьох випадках безпосередньо передбачають жорстке індивідуальне протиборство, агресивні дії учасників змагання $[23,30]$. 
Отже, радикальні зміни, що відбуваються в сучасному спорті найвищих досягнень, зумовлюють необхідність розробки стратегії його розвитку (зокрема, у сфері управління спортивною діяльністю) на національному рівні відповідно до загальносвітових тенденцій. Так, для нашої держави здійснення наукового обгрунтування змін організаційної системи спорту, пошук нових ефективних методів управління визначаються перебудовою соціально-політичного устрою, формуванням ринкових відносин, зниженням показників у спорті вищих досягнень. Досягнення стратегічних цілей у сфері управління спортивною діяльністю передбачає урахування особливостей сформованого в країні соціально-економічного, політичного й національно-культурного середовища, а також загальних процесів, що властиві системі світового спорту [24, 31]. У такому разі спорт як об'єкт управління буде представлений як компонент соціальної системи, що перебуває у взаємозв’язках і взаємодії $з$ іншими ії компонентами.

\section{ЛIТЕРАТУРА}

1. Пилипишин В.П. Поняття та основні риси державного управління [Електронний ресурс] Режим доступу:

http://archive.nbuv.gov.ua/portal/soc_gum/Yurnip/2011_2/Pylypyshyn.pdf.

2. Кочеткова А.И. Введение в организационное поведение и организационное моделирование. - М., 2003. - 944 с.

3. Гасюк I. Функції державного управління розвитком фізичної культури і спорту в Україні // Ефективність державного управління. - 2010. Вип. 24. - С. 175-179.

4. Попов П.М. Оптимальное управление в ходе эволюционного развития процессов и систем. - Ульяновск, 2000. - 148 с.

5. Гасюк І.Л. Теоретичне обгрунтування принципів оптимізації державного управління розвитком фізичної культури і спорту [Електронний ресурс] Режим доступу: http://www.dbuapa.dp.ua/zbirnik/2010-01/10gilfks.pdf.

6. Ведернікова O.A. Менеджмент знань як складова стратегічного інноваційного менеджменту [Електронний ресурс]. Режим доступу: http://archive.nbuv.gov.ua/portal/natural/vcpi/TPtEV/2010_6/stati/Vederniko.pdf.

7. Переверзин И.И. Физическая культура и спорт как объект отраслевого менеджмента // Юбилейный сборник трудов ученых РГАФК, посвященный 80-летию академии. - М., 1998. - Т.2. - С. 84-86.

8. Дубинин Н.П. Новое в современной генетике. - М., 1986. - 221 с. 
9. Дубинин Н.П. Биологические и социальные факторы в развитии человека // Вопросы философии. - 1977. - №2. - С.46-57.

10. Биологическое и социальное в развитии человека. - М., 1977. -228 с.

11. Лубышева Л.И. Социальное и биологическое в физической культуре человека в аспекте методологического анализа // Теория и практика физической культуры. - 1996. - № 1. - С.2-4.

12. Виленский М.Я. Формирование физической культуры личности учителя в процессе его профессиональной подготовки : автореф. дисс. ... докт. пед. наук. - М., 1990. - 54 с.

13. Соловьев Г.М. Генезис становления современного целеполагания по физической культуре в системе образования // Теория и практика физической культуры. - 2003. - № 8. - С. 10-14.

14. Bыдрин B.M. Физическая культура - вид культуры личности и общества (Опыт историко-методологического анализа проблем). - СПб., 2004. $-153 \mathrm{c}$.

15. Быховская И.М. Человеческая телесность как объект социокультурного анализа (история проблемы и методологические принципы ее анализа) // Труды ученых ГЦОЛИФКа: 75 лет: Ежегодник. - М., 1993. - С. 58-68.

16. Быховская И.М. Человеческая телесность в социокультурном измерении: традиции и современность. - М., 1993. - 179 с.

17. Быховская И.М. Физическая культура как практическая аксиология человеческого тела: методологические основания анализа проблемы // Физическая культура: воспитание, образование, тренировка. - 1996. №2. - С. 6-9.

18. Визитей Н.Н. Физическая культура личности (Проблема человеческой телесности: методологические, социально-философские, педагогические аспекты). - Кишинев, 1989. - 110 с.

19. Лубышева Л.И. Концепция формирования физической культуры человека. - М., 1992. - 120 с.

20.Лубышева Л.И. Социальное и биологическое в физической культуре человека в аспекте методологического анализа // Теория и практика физической культуры. - 1996. - № 1. - С.2-4.

21.Бальсевич B.К. Физическая культура: молодежь и современность // Теория и практика физической культуры. - 1995. - №4. - С. 2-8.

22.Зверев А. Свет и тени арены // Глэнвилл Б. Олимпиец. - М., 1989. C. 5-18.

23. Визитей Н.Н. Спортивная деятельность как социальный феномен : автореф. дисс.... докт. филос. наук. - М., 1985. - 38 с.

24. Борисова $O$. Система організації та управління професійним тенісом у сучасних умовах: особливості ії функціонування // Молода спортивна наука України. - 2010. - Т.4. - С.31-37. 
Завальнюк О. Спорт як системний об'єкт управління.

Сучасний спорт - це складний системний об'єкт управління. Як i будь-яка сфера суспільної діяльності, він потребує упорядкування, системності, організації, які б спрямовували його розвиток у загальнокультурне річище. Міжнародна і вітчизняна системи управління спортом склалися історично. Їх функціонування грунтується на принципах системності, цілісності, людиноцентризму, гуманізму. Втім для досягнення поставлених у спорті цілей управління ним має бути оптимальним. Успішність вирішення проблем у сфері спорту безпосередньо залежить і від побудованої організаційної структури управління. Крім того, управління у сфері спорту має забезпечити поступальний розвиток фізичної складової і духовного світу кожної особистості.

Ключові слова: людина, культура, фізична культура, спорт, управління, функції управління.

Завальнюк Е. Спорт как системный объект управления.

Современный спорт - это сложный системный объект управления. Как и любая сфера общественной деятельности, он нуждается в упорядочении, системности, организации, которые направляли бы его развитие в общекультурное русло. Международная и отечественная системы управления спортом сложились исторически. Их функционирование основывается на принципах системности, целостности, человекоцентризма, гуманизма. Однако для достижения поставленных в спорте целей управление им должно быть оптимальным. Успешность решения проблем в сфере спорта напрямую зависит и от правильно построенной организационной структуры управления. Кроме того, управление в сфере спорта должно обеспечить поступательное развитие физической составляющей и духовного мира каждой личности.

Ключевые слова: человек, культура, физическая культура, спорт, управление, функции управления.

Zavalniuk O. Sports as a system object of management.

Modern sport is a complex system object of management.Like any sphere of public activity it needs streamlining, consistency, organization, which would direct its development in general cultural channel. International and domestic sports management systems were developed historically. Their functioning is based on principles of consistency, integrity, anthropocentrism humanism. However, to achieve set goals in sport management must be optimal. Successfulness of problem solving in the field of sports directly depends on adequate organizational structure management. In addition, management in the field of sport must ensure the progressive development of the physical component and spiritual world of each individual.

Key words: human being, culture, physical culture, sports, management, management functions. 